\title{
BIOCHEMICAL AND TOXICOLOGICAL STUDIES OF SOME PESTICIDES ON COTTON LEAFWORM (Spodoptera littoralis)
}

\author{
Mery M.S. Shenouda ${ }^{1^{\star}}$, Moawad ${ }^{2}$ F.G., Ali ${ }^{2}$ N.E. and Sherifa A.N. El-Sherif ${ }^{1}$
}

1. Bioassay Dept., Central Pesticides Laboratory, Dokki, Giza, Egypt

2. Agric. Biochemistry Dept., Fac. of Agric., Ain Shams Univ., P.O. Box 68, Hadayek Shobra 11241, Cairo, Egypt

${ }^{*}$ Corresponding author: Marymagdy1087@gmail.com orded insignificant decrease in GST levels. The total body proteins of $2^{\text {nd }}$ instar larval of $S$. littoralis treated with $\mathrm{LC}_{25}$ of insecticides performed by SDS-PAGE. Control and different treatments were separated into 56 different bands according to their relative frequencies ( $R_{f}$ values), and molecular weights (MW). Samples of electrophoresis were carried out for three different insecticides namely chlorphyrifos, spinosad and lufenuron which used to treat insects. The treatment with insecticides on protein gel electrophoresis led to detection of new bands, and disappeared some bands in comparison to control. It is concluded that treatment with insecticides have strong efficacy on the soluble protein in the body of insects.

Keywords: Chlorpyrifos, Spinosad, Lufenuron, Biochemical study, Protein gel electrophoresis, $S$. littoralis.

\section{INTRODUCTION}

The cotton leafworm, $S$. littoralis is one of the most important insect. It is considered one of the most destructive polyphagous agricultural pest attacking different field crops, cotton, vegetables and lead to severe damage to them. As it is known, cotton plant is a crop of great economic importance in Egypt. The attack of pests to cotton lead to low yield which is related to damage in bolls as a result of attacking cotton leafworm to the crop. The control of cotton leafworm is done by using the chemical insecticides and this way is considered complicate due to the resistance of pests to these insecticides. The most economically and ecologically suitable insecticides are chlorpyrifos, spinosad and lufenuron. 
Chlorpyrifos belongs to organophosphorothionates insecticides. It has been used in wide variety against agricultural crops. It is a non-systemic anticholinesterase activity with contact, stomach and respiratory action.

Spinosad is a neurotoxic insecticide effect on the nervous system of insects by contact or ingestion stomach. It is have a unique mechanism of action (MOA) involving disruption of nicotinic acetylcholine receptors. It causes their muscles to flex uncontrollably. This leads to paralysis and ultimately their death (Kirst 2010).

The activators of enzyme may be components of the enzyme which have been lost during purification, or they may be metabolites that act as control signals in vivo, binding to specific sites on an enzyme lead it to active conformation and some enzymes require specific ion because the enzyme acts on a complex by substrate and cation. The increase in activity of enzyme is due to detoxification of enzyme against foreign compounds.

The substrate-binding cleft contains catalytic groups provided by the enzyme, and these participate in the reaction. The catalytic groups maybe donate protons to, or accept protons from. The catalytic groups maybe amino acid side chains, such as $-\mathrm{COOH},-\mathrm{NH}_{2},-\mathrm{OH}$ and $-\mathrm{SH}$ or maybe provided by non protein components of the enzyme called prosthetic groups. Some enzymes show specific ion requirements such as $\mathrm{Mg}^{+2}$, $\mathrm{Mn}^{+2}, \mathrm{Cu}^{+2}$ or $\mathrm{Ca}^{+2}$.

The insect esterases can either cause broadspectrum resistance to various insecticides through rapid binding and slow turnover of insecticide molecules (i.e. sequestration) or cause narrowspectrum resistance to a very restricted range of insecticides containing a common ester linkage, such as malathion through rapid metabolism of the insecticides (Karunaratne et al 1995).

The tested IGRs induced a reduction in the activities of acid phosphatase and alpha and beta esterases. Therefore the tested IGRs may be not detoxify by these enzymes (Bakr et al 2013)

Detoxification enzymes in insects are generally demonstrated as the enzymatic defens against foreign compounds and play significant roles in maintaining their normal physiological function ( $\mathbf{L i}$ and Liu, 2007).

A member of the esterase cluster probably plays a role in the detoxification of xenobiotic esters (Gacar and Tasksn, 2009) increased esterase activity is am ajar mechanism of insecticide insensitivity or even resistance is many insect species (Zhou et al 2002).

\section{This investigation aimed to study}

1- Evaluate the efficacy of chemical insecticides (chlorphyrifos), spinosyns group (spinosad) and insect growth regulatorin (lufenuron) in comparison with control against the laboratory strain of Spodoptera littoralis.

2- Study the effects of the tested insecticides at $\mathrm{LC}_{25}$ values on some biochemical aspects (i.e.acetylcholinesterase, glutathione-stransferase (GST), chitinase, phenoloxidase, aspartate (AST) and alanine (ALT) aminotransferases, $\alpha$-Esterase, total protein and Gel electrophorsis) in the insects homogenate of insect laboratory.

\section{MATERIALS AND METHODS}

\section{Test insect}

Laboratory strain: The laboratory strain of cotton leaf-worm Spodoptera littoralis (Boisd.) was provided by Central Agriculture Pesticides Laboratory (CAPL), Dokki, Giza. The culture was reared using the technique described by El-Defrawi et al (1964). The obtained strain has been kept under laboratory conditions at $25 \pm 2^{\circ} \mathrm{C}$ and $65 \pm 5 \%$ R.H. Pesticide: The formulation of spinosad used in the bioassay wastracer ${ }^{\circledR} 24 \%$ sc obtained from Dow Agro Sciences Co.,UK. chlorphyrifos (Dursban ${ }^{\circledR} 48 \%$ EC) from Dow Agro Sciences Co.,UK. and lufenuron (Match® $5 \%$ EC.) from Syngenta Co.

Bioassay test: Five different concentrations of each tested insecticide were prepared from the stock solutions by diluting with water (v/v) in volumetric flasks to give the necessary concentrations which produce mortality between $20-80 \%$ of each insecticide. The mortality was corrected by Abbott formula (Abbott, 1925).

\section{Determination of the LC values for tested in- secticides groups}

The toxicity of the tested insecticides against the $2^{\text {nd }}$ instar larvae of susceptible strain and

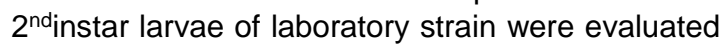
using leaf dipping technique according to (Shepard 1958). Ten healthy $2^{\text {th }}$ instar larvae with five replications were subjected to each of the treated leaves. For insecticides, the larvae were left to feed on treated leaves for $24 \mathrm{~h}$ in case chlorphyrifos, $72 \mathrm{~h}$ incase spinosad and then the mortality counts were recorded. In case of chitin inhibitor, 
the larvae were exposed and fed on treated leaves for 48 hours. Then after the alive, larvae were transferred onto untreated leaves in clean jars and left to feed for 24 hours after that mortality counts were recorded. The $\mathrm{LC}_{25}$ values for each insecticide were calculated by probit analysis using Ldpline software according to Finney (1971), and the Toxicity index (Ti) was calculated using the following equation (Sun, 1950).

\section{Biochemical study}

\section{A. Determination of enzymes activities}

1- Determination of acetylcholinesterase (AChE) was done according to Ellman et al (1961).

2- Determination of glutathion s-transferase (GST) was carried out according to Habig et al (1974).

3- Determination of chitinase was carried out according to Ishaaya and Casida (1974)

4- Determination of phenoloxidase was made according to Ishaaya (1971).

5- Aspartate (AST) and alanine (ALT) aminotransferases was determined using the method of Reitman and Frankle (1957).

6- The method of Van Asperen (1962) was used to determine $\alpha$-esterases.

7- Determination of total soluble proteins was carried out according to Bradford (1976).

\section{B. Fractionation of protein patterns using SDS- PAGE}

Ten percent of acrylamide gel was used and was prepared according to Hames (1987). Equal protein amounts from the samples were mixed with the sample buffer at aratio $1: 1$ and incubated for 5 min in a (water bath) at $100^{\circ} \mathrm{C}$. Each sample was loaded in separate well of the gel and the electrophoresis run was carried out at $100 \mathrm{~V}$ for $1.5 \mathrm{~h}$,

After the running finished the gel was stained in coomassie blue solution overnight. The gel was destaine using acetic acid: ethanol (8:25) until clearing the background. The bands on gel were determined using the software TotalLab 1D.

Data analysis: The obtained data subjected to analysis of variance using proc. ANOVA in SAS, (SAS Institute, 1998). Mean separation was conducted using LSD in the same program at a significant level of $P \leq 0.05$.

\section{RESULTS AND DISCUSSION}

\section{Laboratory strain}

\section{Toxicological and biochemical studies on the laboratory strains}

Data in Table (1) represent the $\mathrm{LC}_{25}$ values of chlorphyrifos, spinosad and lufenuron for the $2^{\text {nd }}$ larval instar of S.littoralis. The $\mathrm{LC}_{25}$ values were $2.21,8.1$ and $0.0005 \mathrm{ppm}$ for the compounds chlorphyrifos, spinosad and lufenuron, respectively.

From these data the more effect of the tested compounds was lufenuron followed by chlorphyrifos and spinosad. The results show a significant difference in the toxicity to $S$. littoralis and the differences in $\mathrm{LC}_{25} \& \mathrm{LC}_{50} \& \mathrm{LC}_{90}$ values may be different modes of action of the tested insecticides. EL-Khayat et al (2012) reported that, the treatment with chlorpyrifos against cotton leaf worm $S$. littoralis $2^{\text {nd }}$ and $4^{\text {th }}$ instar larvae recorded high mortality for insect.) El-Naggar (2013) study the toxicity of two bio-insecticides under group spinosyns which was spinosad and spinetoram against $4^{\text {th }}$ larval instar of $S$. littoralis (Boisd). It was shown that the spinetoram was more toxic than spinosad. Megahed et al (2013) investigated the effects of three bio-insecticides namely emamectin benzoate, abamectin, and spinosad on $4^{\text {th }}$ larval instar of $S$. littoralis using leaf dipping technique .The data recorded that the effect of $\mathrm{LC}_{50}$ after 24hwere emamectin benzoate $>$ abamectin > spinosad. Osman and Mahmoud (2008) mentioned effect that the insecticide lufenuron had a strong efficacy against eggs mass and $3^{\text {rd }} \& 5^{\text {th }}$ larval instars of S.littoralis, but Sabri et al (2016) showed that lufenuron had low toxicity against $S$. littoralis larvae.

2. Effect of the tested compounds on the activities of some enzymes

2.1. Effect on acetylcholinesterase (AchE), Glutathione S-transferase (GST) and $\alpha$-esterases ( $\alpha$-EST) activity

\subsubsection{Effect on acetylcholinesterase (AchE)}

The data in Table (2) shows that all tested insecticides increased the acetylcholinesterase in homogenates of the $2^{\text {nd }}$ instar larvae. It was noticed that $\mathrm{LC}_{25}$ of chlorphyrifos and lufenuron reported significant difference comparing with control (50\%) and (200\%), respectively, while spinosad caused insignificant difference. This result agree with that obtained by Fetoh and Asiry (2013). 
Table 1. The toxicity insecticides and chitin synthesis inhibitor on $2^{\text {nd }}$ larval instar of susceptibility $S$. littoralis

\begin{tabular}{|c|c|c|c|c|c|}
\hline Insecticides & $\begin{array}{c}\text { LC } 25(\mathrm{ppm}) \\
\text { (95\%FL) }\end{array}$ & $\begin{array}{l}\text { LC } 50 \text { (ppm) } \\
\text { (95\% FL) }\end{array}$ & $\begin{array}{l}\text { Slope } \\
\pm \text { S.E. }\end{array}$ & $\begin{array}{c}\text { LC }_{90} \text { (ppm) } \\
\text { (95\% FL) }\end{array}$ & $\mathrm{Ti} \%$ \\
\hline Chlorphyrifos & $\begin{array}{c}2.21 \\
(0.99-3.60)\end{array}$ & $\begin{array}{c}6.25 \\
(3.89-9.32)\end{array}$ & $1.49 \pm 0.24$ & $\begin{array}{c}44.96 \\
(26.35-111.59)\end{array}$ & 0.24 \\
\hline Spinosad & $\begin{array}{c}8.1 \\
(2.57-14.19)\end{array}$ & $\begin{array}{c}29.86 \\
(17.94-49.62)\end{array}$ & $1.19 \pm 0.26$ & $\begin{array}{c}355.98 \\
(153.93-2506.29)\end{array}$ & 0.05 \\
\hline Lufenuron & $\begin{array}{c}0.0005 \\
(--0.0027)\end{array}$ & $\begin{array}{c}0.015 \\
(0.0031-0.051)\end{array}$ & $0.46 \pm 0.10$ & $\begin{array}{c}9.38 \\
(1.28-995.41)\end{array}$ & 100 \\
\hline
\end{tabular}

FL: Fiducial limits SE: Standard error Ti: Toxicity index

whofound the AChE activity for $4^{\text {th }}$ larval instar of S.littoralis treated with chlorpyrifos was increased. Megahed et al (2013) found that spinosad caused maximum level of the change percentage of AChE activity at $48 \mathrm{~h}$, while the minimum level was noticed after $72 \mathrm{~h}$. The insensitivity of the target site to organophosphates and pyrethroids is predominantly due to the activity of the acetylcholine esterase enzyme (AChE) Baek et al (2005).

\subsubsection{Effect on glutathione s-transferase (GST)}

The data in Table (2) show that spinosad significantly decrease the glutathione s-transferase (GST) levels (-35.88\%) comparing to the control, whereas both of chlorphyrifos and lufenuron showed insignificant increase and decrease in GST levels, respectively. The obtained data in harmony with Abou-Taleb et al (2015) the effect of lufenuron on GST activity in S. littoralis which was decreased.

\subsubsection{Effect on $\alpha$-esterases ( $\alpha$-EST) activity}

The data in Table (2) show the affect of all tested insecticides on $\alpha$-esterases ( $\alpha$-EST) the data indicated that spinosad and lufenuron caused significant increase in comparion with control $(8.68 \%)$ and ( $91.88 \%)$, respectively. Whereas the $\mathrm{LC}_{25}$ of chlorphyrifos recorded significant decrease $(-40.19 \%)$. This result disagree with that obtained by Dahi et al (2017) who noticed that the treatments with spinetoram and chlorpyrifos against S.littoralis $4^{\text {th }}$ larval instar led to increase the level of $\alpha$-esterase activity in the insect. The insect esterases can cause resistance to some insecticides through rapid binding and slow turnover of insecticide molecule (Karunaratne et al 1995). Zhou et al (2002) and El-Sheikh (2012) showed that the insecticide resistance maybe due to some resistance mechanisms such as increased detoxification against some of insecticides. The resistance in cotton leafworm is attributed to increase detoxification by increasing activity of esterases, oxides and/or glutathione s-transferases. On the contrary some insecticides lead to inhibition of some enzyme, e.g. spinosad and lufenuron led to decrease activity of GST. Chlorphyrifos, spinosad and lufenuron led to increase acetyl cholinesterase activity owing to the detoxification of this enzyme. Moreover chlorphyrifos induce enhancement in glutathione s-transferase (GST). Through complexing in many reactions catalysis apart $(R)$ of the foreign compound $R X$ that is transferred to the thiol group of glutathione, since its content cysteine, glycerin, glutamic acid. The hydrogen atom of cysteine thiol group is transferred to the residue $X$ to give a substance $H X$. The latter is often a dealkylated or dearylated derivative of $\mathrm{RX}$ with low toxicity, but spinosad and lufenuron decreased the activity of this enzyme. As it is known glutathione is tripeptide and it conjugates with foreign compounds to give complex of compounds. Walker (1975) mentioned that glutamic acid is hydrolytically removed, a cysteine desivatives of the foreign compounds remains, but in insects glutathione conjugates tend to either excreted unchanged or consented to cysteine rather than acetyl cysteine derivatives, for this reason GST can conjugate with insecticides via (-SH) group, moreover the GST is a $26 \mathrm{KDa}$ protein which occurs as a dimer, each monomer has two domains one that bind GSH and 
Table 2. Changes of acetylcholinesterase (AchE), Glutathione S-transferase (GST) and a-esterases ( $\alpha$ EST) activity in the body homogenate of tested insects treated with some insecticide at LC $_{25}$ after $24,72 \mathrm{~h}$ of treatment

\begin{tabular}{|c|c|c|c|c|c|c|}
\hline \multirow[t]{2}{*}{$\begin{array}{l}\text { Insecticides } \\
\text { treatments }\end{array}$} & \multicolumn{2}{|c|}{$\begin{array}{c}\text { AChE } \\
(\mu \mathrm{mol} / \mathrm{per} \min / \mathrm{mg} \text { total } \\
\text { protein) }\end{array}$} & \multicolumn{2}{|c|}{$\begin{array}{c}\text { GST } \\
(\mathrm{nm} / \mathrm{min} / \mathrm{mg} \text { total protein })\end{array}$} & \multicolumn{2}{|c|}{$\begin{array}{c}\alpha-E S T \\
\text { (ug } \alpha-n a p h t h o l / m i n / m l / m g \\
\text { total protein) }\end{array}$} \\
\hline & ${ }^{*}$ Mean \pm SE & $\begin{array}{c}\text { Change } \\
\%\end{array}$ & ${ }^{*}$ Mean \pm SE & $\begin{array}{c}\text { Change } \\
\%\end{array}$ & ${ }^{*}$ Mean \pm SE & $\begin{array}{c}\text { Change } \\
\%\end{array}$ \\
\hline Chlorphyrifos & $0.009 \pm 0.00003^{*}$ & 50 & $0.291 \pm 0.012$ & 22.78 & $68.54 \pm 1.54^{*}$ & -40.19 \\
\hline Spinosad & $0.0096 \pm 0.0005$ & 6.67 & $0.243 \pm 0.019^{*}$ & -35.88 & $123.27 \pm 1.60^{*}$ & 8.68 \\
\hline Lufenuron & $0.027 \pm 0.0004^{*}$ & 200 & $0.352 \pm 0.067$ & -7.12 & $217.63 \pm 3.56^{*}$ & 91.88 \\
\hline Contrc & $0.006 \pm 0.0001$ & ---- & $0.237 \pm 0.009$ & --- & $114.60 \pm 1.53$ & --- \\
\hline Control 72h & $0.009 \pm 0.0003$ & ---- & $0.379 \pm 0.015$ & ---- & $113.42 \pm 1.00$ & ---- \\
\hline
\end{tabular}

${ }^{*}$ Mean with the same letter (s) are not significantly different $(\mathrm{P}<0.05)$.

Change $\%=($ Test-Control) $/$ Control $\times 100$

the other all helical that binds the substrate. The residue is serine. Scrine $-\mathrm{OH}$ can conjugate with lufenuron or spinosad insecticides via nitrogen atom or via oxygen atom, and correspondingly induced inhibition of enzyme. Spinosad and lufenuron insecticides increased the activities of $\alpha$ esterase and this result is due to the detoxification of $\alpha$-esterase. On the contrary chlorphyrifos decreased the activity of $\alpha$-esterase. The active side of $\alpha$-esterase contains a catalytic tied formed by Ser-Asp-His residues. These face it may be conjugate with chlorphyrifos via -OH (serine) or with carboxylic group (Asp) or with nitrogen in histidine, which lead to inhibition of enzyme.

2.2. Effect of insecticides on total protein, aspartate amino transferase (AST) and alanine amino transferases (ALT) activities

\subsubsection{Effect of insecticides on total protein}

Table (3) show the total protein in homogenates of the $2^{\text {nd }}$ instar larvae. The data indicated that $\mathrm{LC}_{25}$ of chlorphyris and lufenuron caused significant decrease in total protein $(-12.95 \%)$ and $(-38.69 \%)$ compared with control, respectively. The $\mathrm{LC}_{25}$ of spinosad caused nonsignificant increase $(1.31 \%)$. This results are in agreement with that obtained by Fetoh and Asiry (2013) who noticed that the content of total protein was reduced in the $4^{\text {th }}$ larval instar of $S$. littoralis treated with chlorpyri- fos. Awadalla et al (2017) indicated that the treatment with insecticide teflubenzuron belong to IGRs group and insecticide chlorpyrifos belong to organophosphate against $4^{\text {th }}$ larval instar of $S$. littoralis caused decrease the total protein content.This results disagree with that obtained by Megahed et al (2013) who found that spinosad significantly lowered total protein and caused the reduction of protein content and it may be due to inhibition of DNA and RNA synthesis.

\subsubsection{Effect of insecticides on aspartate ( AST ) and alanine (ALT) amino transferases activities}

Table (3) show the aspartate amino transferases (AST) in homogenates of the $2^{\text {nd }}$ instar larvae. The data indicated that $\mathrm{LC}_{25}$ of spinosad and lufenuron increased significantly the enzyme activity $(35 \%)$ and $(57.22 \%)$, respectively. Whereas the $\mathrm{LC}_{25}$ of chlorphyrifos caused significant decrease ($84.18 \%$ ), but for alanine amino transferases (ALT) the data show that $\mathrm{LC}_{25}$ of spinosad and lufenuron led to significant increase (38.09\%) and (388.19\%) compared with control, respectively. The $\mathrm{LC}_{25}$ of chlorphyrifos caused nonsignificant decrease $(-5.45 \%)$. Biddinger et al (1996) and Li and Liu (2007) noticed that the increase in activity of enzyme against insecticides may be due to the detoxification of these enzyme in insects which is considered defense against foreign compounds 
Table 3. Changes of total protein, aspartate amino transferase ( AST ) and alanine amino transferases ( $A L T$ ) activity in the body homogenate of tested insects treated with some insecticide at LC 25 after 24,72 hr of treatment

\begin{tabular}{|c|c|c|c|c|c|c|}
\hline \multirow{2}{*}{$\begin{array}{c}\text { Insecticides } \\
\text { treatments }\end{array}$} & \multicolumn{2}{|c|}{$\begin{array}{c}\text { Total protein } \\
(\mathrm{mg} / \mathrm{ml})\end{array}$} & \multicolumn{2}{|c|}{$\begin{array}{c}\text { AST } \\
\text { ( units / ml ) }\end{array}$} & \multicolumn{2}{|c|}{$\begin{array}{c}\text { ALT } \\
\left(\mathrm{u} \times 10^{3} / \mathrm{ml}\right)\end{array}$} \\
\hline & ${ }^{*}$ Mean \pm SE & $\begin{array}{c}\text { Change } \\
\% \\
\end{array}$ & *Mean \pm SE & $\begin{array}{c}\text { Change } \\
\%\end{array}$ & ${ }^{*}$ Mean \pm SE & $\begin{array}{c}\text { Change } \\
\%\end{array}$ \\
\hline Chlorphyrifos & $6.142 \pm 0.063^{*}$ & -12.95 & $0.875 \pm 0.072^{*}$ & -84.18 & $737.5 \pm 7.22$ & -5.45 \\
\hline Spinosad & $6.279 \pm 0.043$ & 1.31 & $6.075 \pm 0.043^{*}$ & 35 & $1450 \pm 11.26^{*}$ & 38.09 \\
\hline Lufenuron & $3.800 \pm 0.130^{*}$ & -38.69 & $7.075 \pm 0.032^{*}$ & 57.22 & $5126 \pm 42.72^{*}$ & 388.19 \\
\hline Control 24h & $7.056 \pm 0.068$ & ---- & $5.530 \pm 0.075$ & ---- & $780 \pm 11.55$ & ---- \\
\hline Control 72h & $6.198 \pm 0.193$ & ---- & $4.500 \pm 0.058$ & ---- & $1050 \pm 28.87$ & ---- \\
\hline
\end{tabular}

${ }^{*}$ Mean with the same letter $(\mathrm{s})$ are not significantly different $(\mathrm{P}<0.05)$.

Change $\%=($ Test-Control) $/$ Control $\times 100$

maintaining their normal physiological functions. Spinosad and lufenuron insecticides increased significantly AST enzyme activity and may be due to detoxification of this enzyme against the two insecticides. Chlorphyrifos decreased significantly the value of AST enzyme. AST consists of two identical subunits the large domain binds the PLP cofactor via an aldmine linkage to the E-amino group of Lys. Other residues in the domain are Asp and Tyr the functional group in aspartic acid i.e. carboxylic group can combine with pyridine in this insecticides and $(-\mathrm{OH})$ from tyrosine can conjugate with oxygen in the structure of chlorphyrifos.

This results agree with that obtained by Megahed et al (2013)who found that the treatment with spinosad against $4^{\text {th }}$ larval instar of S.littoralis increase the activity of (AST)causing the changes in GOT activities .Abou-Taleb et al (2015) noticed increase in (AST) activity in S.littoralislarvae after 48 and $72 \mathrm{~h}$ of treatment with lufenuron. While Mead et al (2008) recorded reduction in the activity of (AST) at $4^{\text {th }}$ larval instar of S.littoralistreated with spinosad.

\subsection{Effect of insecticides on chitinase and phenoloxidase activities}

\subsubsection{Effect of insecticides on chitinase activity}

Table (4) show the activity of chitinase in homogenates of the $2^{\text {nd }}$ instar larvae since $L_{25}$ of spinosad and lufenuron led to significant in- crease in its activity (8.50\%) and (14.96\%), respectively. The $\mathrm{LC}_{25}$ of chlorphyrifos caused nonsignificant increase $(9.16 \%)$.

The obtained results were in not harmony with Gelbic et al (2011) who elucidated that the insecticides tebufenozide and lufenuron inhibited the synthesis of chitin at S.littoralis. The data confirmed that lufenuron is more active than tebufenozide. Fetoh and Asiry (2013) found reduction in the chitinase activity in the $4^{\text {th }}$ larval instar of S.littoralis treated by chlorpyrifos. Lufenuron caused inhibition to the production of chitin; therefore, the larvae are unable to successfully moult into the next stage (Kassem et al 1986).

Verloop (1977) reported increase in chitinase activity when treating pupae with Teflubenzuron due to the secondary effect of chitin synthesis inhibitor. The primary effect involves blocking of incorporation of uridine 5'-diphospho-Nacetylglucose-amine into chitin. Chitin synthetase carried out this reaction through the polymerization step.

\subsubsection{Effect of insecticides on phenoloxidase activity}

Data in Table (4) show the activity of phenoloxidase. $\mathrm{LC}_{25}$ of spinosad and lufenuron caused significant decrease $(-7.02 \%)$ and $(-33.27 \%)$, respectively in comparision with control. The $\mathrm{LC}_{25}$ of chlorphyrifos caused nonsignificant decrease in the activity of phenoloxidase $(-0.44 \%)$. 
Table 4. Changes of Chitinase and Phenoloxidase activity in the body homogenate of tested insects treated with some insecticide at $\mathrm{LC}_{25}$ after $24,72 \mathrm{hrs}$. of treatment

\begin{tabular}{|c|c|c|c|c|}
\hline \multirow{2}{*}{ Insecticides treatments } & \multicolumn{2}{|c|}{$\begin{array}{c}\text { Chitinase } \\
\text { (ng NAG/min/mg total } \\
\text { protein) }\end{array}$} & \multicolumn{2}{c|}{$\begin{array}{c}\text { Phenoloxidase } \\
\text { (O.D. units/min/mg total } \\
\text { protein) }\end{array}$} \\
\cline { 2 - 5 } & ${ }^{*}$ Mean \pm SE & Change \% & ${ }^{*}$ Mean \pm SE & Change \% \\
\hline Chlorphyrifos & $572 \pm 10.59$ & 9.16 & $13.57 \pm 0.19$ & -0.44 \\
Spinosad & $1059 \pm 21.94^{*}$ & 8.50 & $15.37 \pm 0.15^{*}$ & -7.02 \\
Lufenuron & $1122 \pm 27.06^{*}$ & 14.96 & $11.03 \pm 0.26^{*}$ & -33.27 \\
\hline Control 24h & $524 \pm 19.97$ & ---- & $13.63 \pm 0.19$ & ---- \\
Control 72h & $976 \pm 33.83$ & --- & $16.53 \pm 0.32$ & --- \\
\hline
\end{tabular}

*Mean with the same letter $(\mathrm{s})$ are not significantly different $(\mathrm{P}<0.05)$.

Change $\%=($ Test-Control) $/$ Control $\times 100$

This results disagree with that obtained by Fetoh and Asiry (2013) who evaluated the activity of phenoloxidase against $4^{\text {th }}$ larval instar of S.littoralis treated with chlorpyrifos.

The three insecticides decreased the activity of phenoloxidase enzyme. Phenoloxidase enzyme (PO) is a tetramer containing four atoms of copper per molecule and two binding sites. Copper may be acts as a catalyst between enzyme and foreign compounds. The (PO) enzyme is oxidative agent and can reduce oxygen in the three insecticides producing $(-\mathrm{OH})$ group. These factors lead to inhibition and decrease the activity of phenoloxidase enzyme.

\section{Fractionation of protein patterns}

SDS - PAGE was used to the fractionation of the total body proteins of $2^{\text {nd }}$ instar larval of $S$. littoralis treated with $\mathrm{LC}_{25}$. Control and different treatments were separated into 56 different bands according to their relative frequencies $R_{f}$ values, and molecular weights (MW). Samples of electrophoresis were carried out for three different insecticides chlorphyrifos, spinosad and lufenuron that used to treat insects.

\subsection{Treatment with chlorphyrifos}

The results in Fig. (1) revealed that, treatment of laboratory strain with chlorphyrifos at $\mathrm{LC}_{25}$ caused the appearance of several specific protein bands. The bands $\left(1,3,7,8,10,11\right.$ and 12 with $R_{f}$
$0.022,0.238,0.361,0.388,0.436,0.555$ and 0.648 and MW 192.243, 54.113, 39.623, 36.461, 32.538, 28.636 and $25.401 \mathrm{KDa}$ ) were characteristic bands compared with sample lane 1.

\subsection{Treatment with Spinosad}

Fig. (1) shows that the present results revealed that, treatment of laboratory strain with spinosad at $\mathrm{LC}_{25}$ caused the appearance of several specific protein bands No. $(2,6,9,10,12,15,17$ and 19 with $R_{f} 0.035,0.225,0.344,0.396,0.436,0.608$, 0.775 and 0.859 and MW 169.434, 54.826, 41.978, $35.562, \quad 32.538, \quad 26.902, \quad 20.719$ and 17.75 $\mathrm{KDa}$ ), were characteristic bands in comparison with control sample lane 1.

\subsection{Treatment with lufenuron}

Fig. (1) shows that the present results revealed that, treatment of laboratory strain with lufenuron at $\mathrm{LC}_{25}$ caused the appearance of several specific protein bands No. $(2,5,7,10,13,15,17$ and 20 with $R_{f} 0.062,0.142,0.235,0.393,0.442,0.633$, 0.761 and 0.956 and MW 130.062, 73.531, 54.041, $36,32.239,25.901,21.188$ and $14.313 \mathrm{KDa}$ ) were characteristic bands in comparison with control sample lane 1.

Generally, the treatment with insecticides led to detection of new bands, and disappeared some bands in comparison to control. It is concluded that treatment with insecticide has strong efficacy on the soluble protein in the body of insects. 


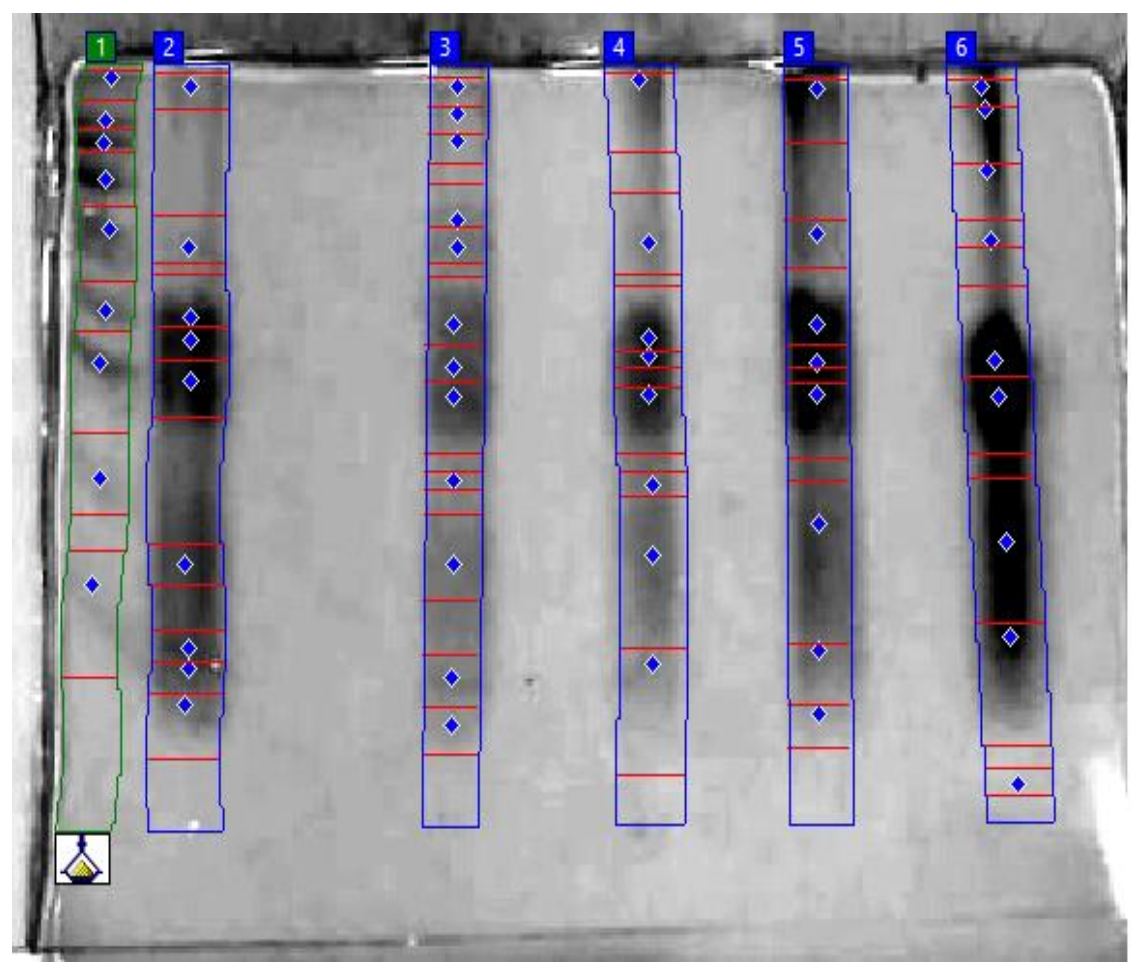

Fig. 1. Protein profile for larval Homogenate of $2^{\text {nd }}$ instar larvae of $S$. littoralis treated with $\mathrm{LC}_{25}$ of chlorphyrifos, spinosad and lufenuron

L1 - Molecular weight standard

L2 - control $24 \mathrm{~h}$

L3 - control $72 \mathrm{~h}$

L4 - treatment with chlorphyrifos

L5 - treatment with spinosad

L6 - treatment with lufenuron

\section{REFERENCES}

Abbott W.S. 1925. A method for computing effectiveness of an insecticide. J. Econ. Entomol., 18(1), 265-267.

Abou-Taleb H.K., Zahran H.E.M. and Abir A. Gad 2015. Biochemical and physiological effects of lufenuron and chlorfluazuron on Spodoptera littoralis (Boisd.) (Lepidopter : Noctuidae). J. Entomol, 12 (2), 77-86.

Awadalla S.S., El-Mezayyen G.A., Bayoumy M.H. and Nesreen E. El-Mowafy 2017. Bioinsecticidal Activity of some Compounds on the Cotton Leafworm, Spodoptera littoralis (Boisd.) under Laboratory Conditions. J. Plant Prot. and Path., Mansoura Univ., Mansoura, Egypt, 8(10), 525 - 528.

Baek J.H., Kim J.I., Lee D.W., Chung B.K., Miyata T. and Lee S.H. 2005. Identification and characterization of ace1-type acetylcholine esterase likely associated with organophosphate resistance in Plutella xylostella. Pesticide Biochemistry and Physiology 81(3), 164-175.

Bakr R.F.A., Nehad M. El-barky, Mona F. Abd El-aziz, Awad M.H. and Abd El-Halim H.M.E. 2013. The activity of some detoxification enzymes in Spodoptera littoralis (Bosid.) larvae (Lepidoptera : Noctuidae) treated with two different insect growth regulators. J. Biolog. Sci., 5(2), 19-27.

Biddinger D.J., Hull L.A. and Mcpheron B.A. 1996. Cross-resistance and synergism in azinphosmethyl resistant and susceptible strains of tufted apple bud moth (Lepidoptera: Tortricidae) to various insect growth regulators and avarmectin. J. Econ. Entomol., 89, 274287. 
Bradford M.M. 1976. A rapid and sensitive method for quantitation of microgram quantities of protein utilizing the principle of protein-dye binding. Anal. Chem., 72, 248-254.

Dahi H.F., Abdel-Rahman A.G., El-Ramby M.M., Walaa E. Gamil, and Doaa S. Rasheed 2017. Insecticides application and the Egyptian cotton leafworm, Spodoptera littoralis (Boisd.) permanent larvae. Egypt. Acad. J. Biolog. Sci., 10(7), 311-322.

El-Defrawi M.E., Toppozada A., Mansour N. and Zeid M. 1964. Toxicological studies on the Egyptian cotton leaf-worm, Prodenia litura F.I. susceptibbility of different larval instars of Prodenia to insecticides. J. Econ. Entomol., 57, 591-593.

El-Khayat E.F., Desuky W.M.H., Azab M.M. and Khedr M.M.A. 2012. Toxic impact of some insect growth regulators and biocides in relative to chlorpyrifos to cotton leafworm, Spodoptera littoralis (Boisd). J. Agric. Res., 90(1), 55-65.

Ellman, G.L., Courtney K.D., Andres V. and Featherstone R.M. 1961. A new and rapid colorimetric determination of acetylcholinesterase activity. Biochem. Pharmacol. 7, 88-95.

El-Naggar J.B.A. 2013. Sublethal effect of certain insecticides on biological and physiological aspects of Spodoptera littoralis (Boisd.). Nat. and Sci. 11(7), 19-25.

El-Sheikh A.E. 2015. Comparative toxicity and sublethal effects of emamectin benzoate, lufenuron and spinosad on Spodoptera littoralis Boisd (Lepidopter: Noctuidae). Crop Protect. 67, 228-234.

El-Sheikh T.A.A. 2012. Biological, biochemical and histological effects of spinosad, Bacillus thuringiensis var. kurstaki and cypermethrin on the Cotton leafworm, Spodoptera littoralis (Boisd.). J. Biolog. Sci., 4(1), 113-124.

Fetoh B.E.A. and Asiry K.A. 2013. Biochemical effects of chlorpyrifos organophosphorous insecticide, camphor plant oil and their mixture on Spodoptera littoralis (Boisd.). Phytopathol. and Plant Protection, 2013. http://dx.doi.org/10.1080/03235408.2013.779 $\underline{073}$

Finney D.J. 1971. Probit Analysis. A statistical treatment of the Sigmoid Response Curve. Cambridge Univ. Press, London, UK, 33 p.

Gacar F. and Tasksn V. 2009. Partial base sequence analysis of MdaE7 gene and aliesterase enzyme activities in field collected populations of housefly (Musca domestica L.) from Mediterranean and Aegean Regions of Turkey. Pestic. Biochem. Physiol., 94, 86-92.

Gelbic I., Manal M. Adel and Hussein H.M. 2011. Effects of Nonsteroidal ecdysone agonist $\mathrm{RH}$ 5992 and chitin biosynthesis inhibitor lufenuron on Spodoptera littoralis (Boisduval, 1833). J. Biol. 6(5), 861-869.

Habig W.H., Pabst M.J. and Jakby W.B. 1974. Glutathion-s-transferase: The first step in mercapturic acid formation. J. Biol. Chem., 249, 7130-7139.

Hames B.D. 1987. Gel electrophoresis (Hames B.D. \& Rickwood D.) $6^{\text {th }}$ ed., IRL Press: pp. 186.

Ishaaya I. 1971. Observations on the phenoloxidase system in the armored scales Aonidi ellaaurantii and chrysomphalus aonidum. Comp. Biochem. Physiol., V39B, 935-943.

Ishaaya I. and Casida J.E. 1974. Dietary TH 6040 alters composition and enzyme activity of housefly larval cuticle. Pesti. Biochem. Physiol., 4, 484-490.

Karunaratne S.H.P.P., Hemingway J., Weerasinghe I.S., Jayawardena K.G.I., Dassanayaka V. and Vaughan A. 1995. Kinetic and molecular differences in the amplified and nonamplified esterases from insecticideresistant and susceptible Culex quinquefasciatus mosquitoes. J. Biolog. Chem., 270, 3112431128.

Kassem S., Sherby S.M., Aly M.I., Zeid M.I. and El-Sebae A.H. 1986. Studies on toxic effects of endotoxin, chitin synthesis inhibitor and mixtures of diflubenzuron with different insecticides on Egyptian cotton leaf worm Spodoptera littoralis (Boisd.). Alexandrian J. Agric. Res. 31, 327-336.

Kirst A.H. 2010. The spinosyn family of insecticides: realizing the potential of natural products research. J. Antibiotics 63, 101-111.

Li X.Z. and Liu Y.H. 2007. Diet influences the detoxification enzyme activity of Bactrocera tau (Walker) (Diptera: Tephritidae). Acta Entomolog. Sinica. 50(10), 989-995.

Mead H.M., Soliman B.A., El-sheakh A.A., AboGhalia A.H. and Desuky W.M.H. 2008. Biochemical studies of the mixtures of some insecticides with surfactants on the $4^{\text {th }}$ instar larvae of cotton leafworm, Spodoptera littoralis (Boisd.). J. Product and Dev., 13(2), 251260.

Megahed M.M.M., El-Tawil M.F., El-Bamby M.M.M. and Abouamer W.L. 2013. Biochemical effects of certain bioinsecticides on cotton 
leaf Worm, Spodoptera littoralis (Boisd.) (Lepidoptera :Noctuidae). J. Agric. and Biolog. Sci., 9(6), 308-317.

Osman M.A.M. and Mahmoud M.F. 2008. Effect of bio-rational insecticides on some biological aspects of the Egyptian cotton leafworm Spodoptera littoralis (Boisd.) (Lepidoptera: Noctuidae). Plant Protect. Sci., 44(4), 147154.

Reitman S. and Frankel S. 1957. Colourimetric method for aspartate and alanine transaminases. Amer. J. Clin. Pathol., 28, 56.

Sabri M.A., Aslam M.S., Hussain D. and Saleem M. 2016. Evaluation of lethal response of biorational insecticides against Spodoptera litura (Lepidoptera: Noctuidae). J. Entomol. and Zool. Studies 4(4), 270-274.

SAS Institute 1998. SAS Users guide. Statistics. SAS Institute, Cary, N.C.

Shepard H.H. 1958. Methods of testing chemicals on insects, 1 ed., Vol. 1. Burgess Publishing Co., Minneapolis, Minnesota, USA, 325 p.
Sun Y.P. 1950. Toxicity index-An improved method of comparing the relative toxicity of insecticides. J. Econ. Entomol., 43, 45-53.

Van Asperen K. 1962. Astudy of house fly esterase by means of sensitive Colourimetric method. J. Insect Physiol., 8, 401-416.

Verloop A. 1977. Benzoylphenyl urea, a new group of larvicides interfering with chitin deposition. Centennial Meeting, American Chemical Society, Division of Pesticide Chemistry, New York, April 1976, America. Chem. Soc., Monogr., 13, 237-270.

Walker C.B. 1975. Organochlorine Insecticide Persiatant organic pollutants, Moriarly F. (ed.). Acadmic press. New York, USA, 73 p.

Zhou X., Scharf M.E., Parimi S., Meinke L.J., Wright R.J., Chandler L.D. and Siegfried B.D. 2002. Diagnostic assays based on esterase mediated resistance mechanisms in western corn rootworms (Coleoptera: Chrysomelidae). J. Economic. Entomology, 95, 12611266. 


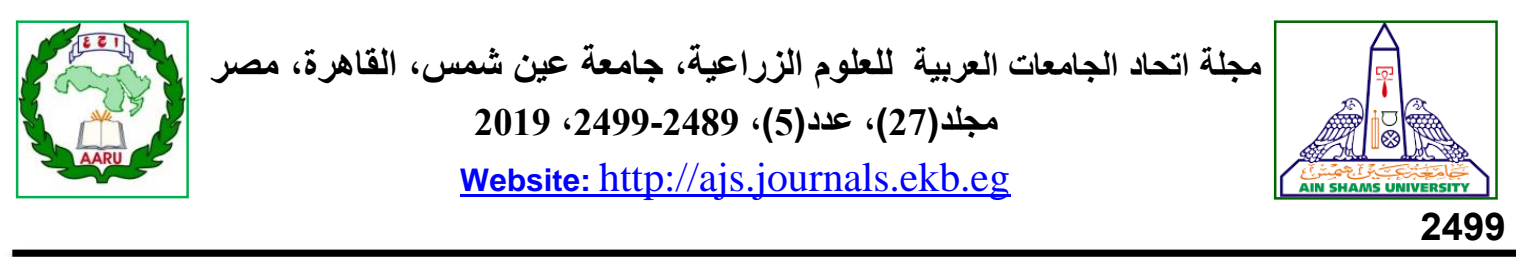

دراسات بيوكيميائية و سمية لبعض المبيدات على دودة ورق القطن

[197]

\author{
ميرى مجدى صبحى شنودة" " - فاروق جندى معوض2 - نجاح الثحات على2 - \\ شريفة عبد الحميد نصر الثريف \\ 1- قسم الاختبارات والبحوث الحيوية - المعمل المركزى للمبيدات - مركز البحوث الزراعية - الدقى - الجيزة - مصر \\ 2- قسم الكيمياء الحيوية الزراعية - كلية الزراعة - جامعة عين شمس - ص.ب. 68 - حدائق شبرا 11241 - القاهرة -
}

مصر

${ }^{*}$ Corresponding author: Marymagdy1087@gmail.com

Received 10 December, 2019

Accepted 15 January, 2020

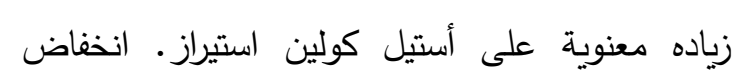
معنوى لسبينوساد على الجلوتاثيون-اسل - ترانسفيريز الخفيز

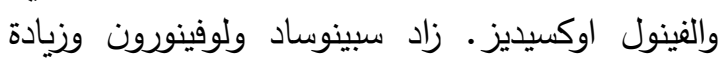
معنوية للانزيم الفا استيريز والكيتينز والانيلين الينين الكينو

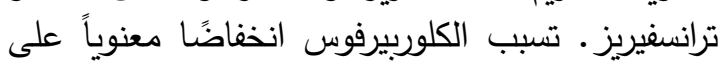

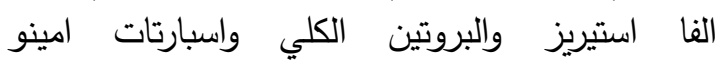

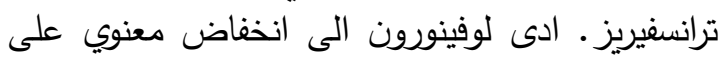

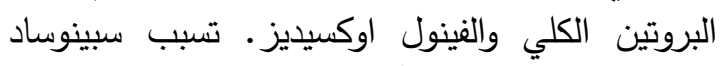
زيادة غير معنوية على أستيل كولين استيريز والبروتين

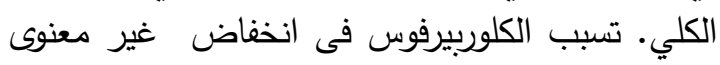

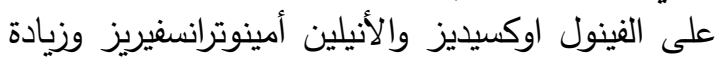

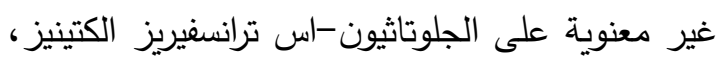

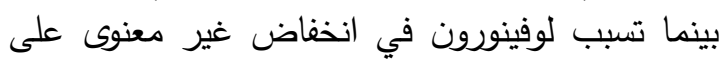

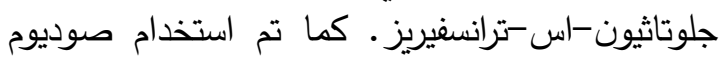

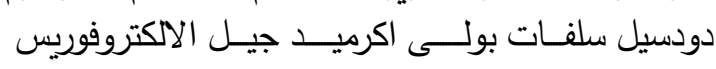

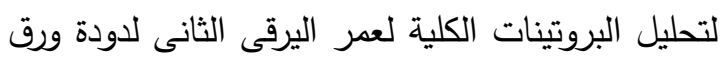

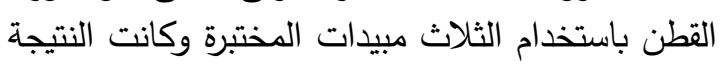

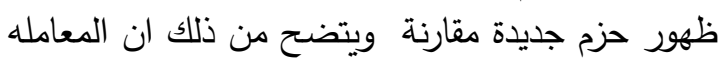
بالمبيدات الحشرية لها فعالية قوية على البروتين الذائب

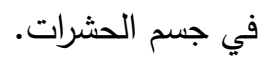

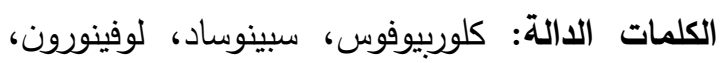
دراسات البيوكيميائية، فصل بروبيو، بروتين بإستخدام التفريد لونيات الكهربائى، دودة ورق القطن فيون فئن

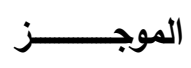

تهاف هذه الدراسة إلى تسليط الضوء على دور بعض المبيدات الحشرية (المبيدات الحشرية الكيميائية كلوبيرفوس (دروسبان اتش 48\%) وسبينوساد (ترسير

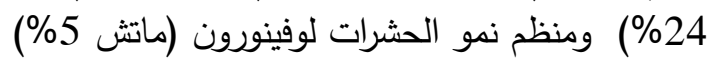

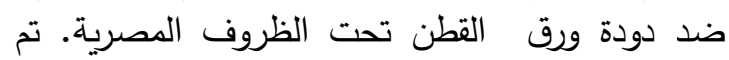
إجراء التأثيرات السمية والتحليل الكيميائي الحيوي ضد ضد الفي السلالة المختبرية للحشرات المستهدفة بعد 24 و 72 ساعة. تم اختبار سمية المبيدات الحشرية لثنلاثة

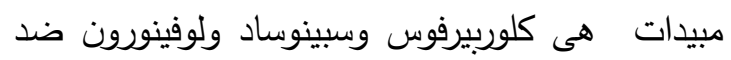

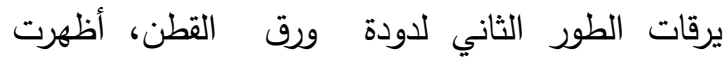

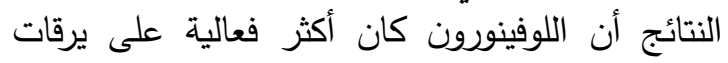

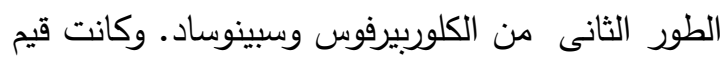

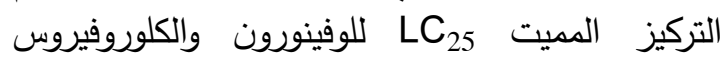

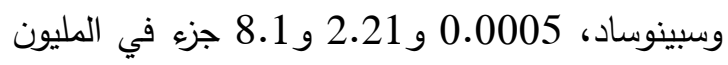
على التوالي. حيث تمت الدراسة الكيميائية الحيوية بهذي ولئه

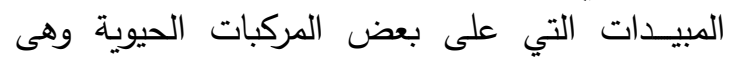

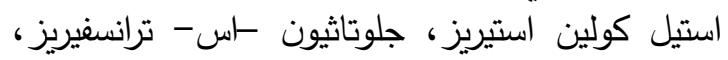

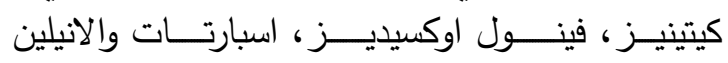

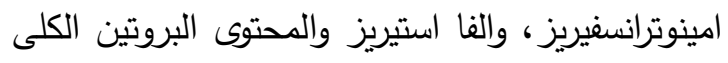

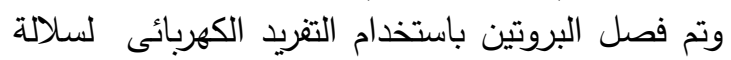

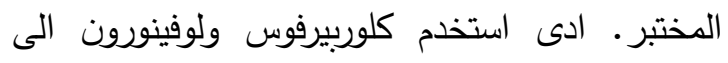

